\title{
Gynecological history, contraceptive use and the risk of ectopic pregnancy: An Indonesian case-control study
}

\author{
Bastaman Basuki
}

\begin{abstract}
Abstrak
Makalah ini merupakan gabungan 4 publikasi hasil penelitian kasus-kontrol risiko kehamilan ektopik terganggu (KET) yang berkaitan dengan riwayat ginekologik dan pemakaian kontrasepsi di 11 kota di Indonesia pada tahun 1989/1990. Kasus adalah KET yang dikonfirmasikan dengan pemeriksaan histopatologik. Satu kasus KET dipadankan dengan kontrol terdiri dari wanita hamil dan 2 wanita menikah yang tidak hamil. Pada perbandingan dengan wanita tidak hamil, peserta aktif IUD tercegah terhadap kemungkinan mengalami konsepsi tubal dan nidasi ektopik, sedangkan pemakaian IUD $\geq 3$ tahun mempertinggi risiko KET tubal lodds rasio suaian $(O R)=2,3$; $95 \%$ interval kepercayaan $(C I)=1,3-4,0$ ). Sedangkan jika kasus dibandingkan dengan wanita hamil, maka KET terdahulu, abortus, keguguran, infeksi pelvik, kebiasaan merokok, dan pemakaian IUD $\geq 3$ tahun merupakan faktor risiko KET. Faktor risiko yang terkuat adalah KET terdahulu (OR suaian $=16,8 ; 95 \%$ CI: 2,1-132,5). Akan tetapi, metode suntikan dan kontrasepsi alamiah dapat mencegah KET. Oleh karena itu dianjurkan agar terhadap wanita yang mempunyai risiko tinggi KET diterapkan diagnosis dini dan pengobatan tepat, serta konseling kepada para (-calon) akseptor dalam memilih dan memakai kontrasepsi yang paling tepat untuk memperkecil kemungkinan KET.
\end{abstract}

\begin{abstract}
This paper is based on four publications on a population-based case-control study in 11 cities in Indonesia in 1989/1990 to assess the risk of ectopic pregnancy (EP) associated with gynecological history, past and current contraceptive use. Cases were EP histopathologically confirmed. Each case was matched by one pregnant control and two non-pregnant married women as controls. In comparison with nonpregnant controls, current IUD use decreased the probabilities of achieving tubal conception and subsequent ectopic nidation, whereas, past $I U D$ use for $>3$ years increased the probabilities (adjusted odds ratio $(O R)=2.3 ; 95 \%$ confidence intervals $(C I)=1.3-4.0$ ). In comparison with pregnant controls, history of previous $E P$, induced abortion, miscarriage, pelvic inflammatory disease, smoking habit, and current IUD use for 3 years or more increased risk of ectopic nidation. The strongest risk factor was previous EP (adjusted OR $=16.8 ; 95 \%$ CI: $2.1-132.5$ ) among past contraceptive users. On the other hand, past injectable and natural contraception prevented ectopic nidation. Thus, it is recommended that for those with identified risk factors for $E P$, early diagnosis and prompt treatment, also a counseling program in choosing and using the most suitable contraceptive method should be provided.
\end{abstract}

Keywords: ectopic pregnancy, gynecological history, contraception, Indonesia

The rate of ectopic pregnancy (EP) has been rising in the past thirty years and has become a major cause of death. ${ }^{1,2}$ Results of previous meta-analysis studies ${ }^{3-5}$ indicate that gynecological infection, history of gynecological and abdominal operation, and contraceptive use may increase the risk of EP. Association of past and current intrauterine device (IUD) use with the increase risk of EP have been reported. However, the results varied considerably. ${ }^{1-4}$ Past hormonal and other natural contraceptive methods seem to be lowering the risk of EP, and smoking habit increases the risk. ${ }^{1,2,5}$

*) Department of Community Medicine, University of Indonesia School of Medicine, Jakarta, Indonesia

This investigation received financial support from the Special Program of Research, Development and Research Training in Human Reproduction, World Health Organization (WHO HRP 87136)
In Indonesia there are more than 20 million current contracepting women using IUDs, pills, injectables, implants, condoms, sterilization, and natural methods. In addition, a large number of Indonesia women are past contraceptive users (Personal communication, Indonesian National Family planning Coordinating Board). Current and past contraceptive users are at risk in developing EP. ${ }^{1-4}$ Separate analysis on the population-based case-control study in Indonesia has been published. ${ }^{6-9}$ The results of the identified risk factors varied if cases were compared to past and current contraceptive users of non-pregnant controls, as well as if cases were compared to past contraceptive users, current IUD users, and among the failures of IUD of pregnant controls.

This paper is an attempt to present a comprehensive figure on the risk factors for tubal conception and ectopic nidation associated with gynecological history, past and current contraceptive use. 


\section{METHODS}

This paper is a summarized result of four previous publications ${ }^{6-9}$ of population-based case-control study which was conducted in 11 cities in Indonesia, namely in Medan, Padang, Palembang, Jakarta, Bandung, Semarang, Yogyakarta, Surabaya, Denpasar, Ujungpandang and Manado, that have teaching hospitals primarily serving defined catchment areas, during the period of 1 April 1989 to 31 August 1990 which referred to $2,222,000$ eligible couples (Personal communication, Indonesian National Family planning Coordinating Board).

Cases were EP that were confirmed by histopathologists by the presence of trophoblast, fetal, or chorionic villi tissue in a sample taken at surgery. The women also had to be married, 15 to 44 years of age at diagnosis, and to reside within one of the defined catchment areas of the hospitals. Cases were identified by treating physicians and referred to a specially trained nursemidwife for interview. Interview was conducted in a hospital within the third or fourth day of hospitalization. During the period, 560 eligible cases were identified and all completed the interviews.

The control groups consisted of pregnant and nonpregnant married women who lived within the catchment area that was served by the participating hospitals. The pregnant control group was clinically pregnant women of less than 20-week of pregnancy. Non-pregnant women controls were excluded from the study if they were found pregnant or were within 6 weeks postpartum. The controls were matched to the cases by catchment area and five-year age interval. Each case was matched by one pregnant control and two nonpregnant controls.

Controls were randomly selected from the catchment areas of participating hospitals in the following manner. For each area, subdistricts consisting of 40-60 neighborhoods were identified, and neighborhoods were randomly selected from this list. From each neighborhood 20 to 40 eligible women were included. Eligibility was determined at four-month intervals through a door-to-door census. List of potential controls were ordered by age group of five-year intervals (15-19, 20-24, 25-29, 30-34, 35-39, and 40-44 years), and catchment area. One pregnant and 2 non-pregnant controls were randomly matched to each case. If a selected control was not available for an interview after two return visits to her home, an alternative control was selected.
A nurse/midwife interviewed control women at their homes. Although the interviewers of cases and controls differed, the interviewers were similarly trained specifically for this study. A total of 560 pregnant and 1120 non-pregnant controls were interviewed.

For cases and pregnant controls, information collected pertained to exposures and characteristics prior to the estimated date of conception of EP. Each woman was asked to report her current method, length of time she had been continuously using that last method, the longest duration of using that method, and the total duration of use. Similar information was collected regarding use of every other birth control method that had previously been used, whether or not any symptoms of pelvic inflammatory disease $(\mathrm{PID})$ were present. PID was defined by a history of treatment for PID or symptoms of lower abdominal pain and fever.

Current users of any contraceptive methods at the estimated date of conception were defined as follows. IUD, pill, minipill, condom, vaginal jelly, or natural method current users were those who less than one month before the estimated date of conception were still using any of the above contraceptive method, As for injectables and implant, current users were those who less than three months before the estimated date of conception had injectable or implant contraceptive methods.

This study was approved by the Ethical Committee of the Indonesian National Family Planning Coordinating Board.

Based on the available data of the population-based case-control study, separate analyses were conducted to identify the risk of EP associated with the risk factors of past IUD use and current use of a contraceptive using non-pregnant controls to compare the odds of ectopic and subsequent nidation. In order to identify risk of the odds of ectopic nidation in the cases and controls associated with risk factors of past and current contraceptive use, particularly IUD use, the analysis was using comparison of pregnant controls.

Four published reports ${ }^{6-9}$ on the population-based casecontrol study in Indonesia are available namely: Paper I analyzed the risk of tubal EP associated with duration and number of episodes of past and current IUD use using non-pregnant controls; ${ }^{6}$ Paper II, analyzed of the risk of EP associated with gynecological, past contra-ceptives use, and smoking habit using pregnant controls; ${ }^{7}$ Paper III analyzed the risk of EP associated with duration, 
number of current IUD use episodes relative to pregnant women with no contraceptive use $;{ }^{8}$ Paper IV analyzed the risk of EP associated with current IUD use between cases and pregnant women with IUD failure.

Paper I used tubal EP cases and non-pregnant controls. For the analysis of current IUD use on risk of tubal EP to compare current IUD users to the other contraceptive use, women who were nulligravid, and had prior EP were excluded. Four hundred and sixteen cases and 1076 non-pregnant controls were available. For the analysis of past IUD use on risk of tubal pregnancy, cases or non-pregnant controls who were nulligravid with prior EP, had undergone sterilization, and with undergone sterilization or with husband that were sterilized, current IUD users were excluded, leaving 360 cases and 776 pregnant controls available. ${ }^{6}$

Paper II, the past contraceptives use analysis, using all types of EP cases and pregnant controls who were not current contraceptive users at time of estimated conception. Four hundred and fifty six cases and 506 pregnant controls were available.?

Paper III included current IUD users and no contraceptive users at the estimated date of conception among cases and pregnant controls, leaving $510 \mathrm{EP}$ cases and 519 pregnant controls for the analysis. ${ }^{8}$

Paper IV consists of only cases and pregnant women, who at the estimate date of conception were still using the IUD. There were 54 cases and 13 pregnant controls available. ${ }^{9}$

A number of risk factors were examined as potential confounders and/or effect modifiers as listed on Table 1 and 2. Unconditional logistic regression analysis ${ }^{10}$ was used to control the confounding effects of risk factors on the relationship between the risk factors and EP. A risk factor was considered to be a potential confounder if upon completing of the univariate test has a p-value < 0.25 which was considered as a candidate for the multivariate model along with all risk factors of known biological importance. ${ }^{11}$ Characteristics that fulfilled this definition as confounders were included by the method of maximum likelihood. Ninety-five percent confidence intervals were based on the standard error of coefficient estimates. Relative risks approximately by odds ratios were estimated by methods of maximum likelihood using Egret software. ${ }^{12}$

\section{RESULTS}

More EP was located on the right side (54.9\%) than on the left side, whereas on both sides EP were 3 cases. Most cases were tubal EP (85.9\%), which consisted of inner third tubular EP ( 78 cases), middle third tubular EP 215 cases), and outer third tubular EP (188 cases). The other EP types were intramural or cornual (17 cases), ovarian (10 cases), tubular abortion or implantation not identified (37 cases), and other types (15 cases).

Cases and non-pregnant controls were similarly distributed with respect to age and study center. Smoking habit and history of induced or spontaneous abortion were mote frequently reported among the cases compared to pregnant controls, as well as there were fewer live births and more episodes of PID among the cases (Table 1).

Table 1. The percentage of cases and non-pregnant controls

\begin{tabular}{|c|c|c|c|c|}
\hline & \multicolumn{2}{|c|}{$\begin{array}{l}\text { Past IUD use } \\
\text { analysis }\end{array}$} & \multicolumn{2}{|c|}{$\begin{array}{c}\text { Current IUD use } \\
\text { analysis }\end{array}$} \\
\hline & $\begin{array}{c}\text { Cases } \\
(\mathrm{N}=360)\end{array}$ & $\begin{array}{c}\text { Non-pregnant } \\
\text { controls } \\
(\mathrm{N}=776)\end{array}$ & $\begin{array}{c}\text { Cases } \\
(\mathrm{N}=416)\end{array}$ & $\begin{array}{c}\text { Non-pregnant } \\
\text { controls } \\
(\mathrm{N}=1076)\end{array}$ \\
\hline \multicolumn{5}{|l|}{ Study center } \\
\hline Medan & 12.2 & 12.1 & 11.5 & 11.5 \\
\hline Padang & 5.3 & 5.8 & 5.8 & 5.8 \\
\hline Palembang & 5.8 & 6.6 & 5.3 & 5.3 \\
\hline Jakarta & 24.2 & 24.1 & 23.1 & 23.1 \\
\hline Bandung & 10.8 & 13.8 & 12.0 & 12.0 \\
\hline Semarang & 5.6 & 4.9 & 5.0 & 5.0 \\
\hline Yogyakarta & 4.4 & 5.7 & 5.8 & 5.8 \\
\hline Surabaya & 9.7 & 8.8 & 9.1 & 9.1 \\
\hline Denpasar & 8.1 & 4.5 & 8.7 & 8.7 \\
\hline Ujungpandang & 7.2 & 9.0 & 7.7 & 7.7 \\
\hline Manado & 6.7 & 4.8 & 6.0 & \\
\hline \multicolumn{5}{|l|}{ Age group (years) } \\
\hline $15-19$ & 0.8 & 2.4 & 0.7 & 1.9 \\
\hline $20-24$ & 17.5 & 18.4 & 16.3 & 17.0 \\
\hline $25-29$ & 39.2 & 41.1 & 38.2 & 39.5 \\
\hline $30-34$ & 27.2 & 25.1 & 27.6 & 27.0 \\
\hline $35-39$ & 13.9 & 11.7 & 15.1 & 12.9 \\
\hline $40-44$ & 1.4 & 1.0 & 1.9 & 1.8 \\
\hline \multicolumn{5}{|l|}{ Parity } \\
\hline 0 & 6.1 & 1.2 & 5.3 & 0.8 \\
\hline 1 & 36.7 & 27.2 & 33.7 & 24.8 \\
\hline 2 & 28.6 & 30.3 & 28.1 & 30.9 \\
\hline 3 or more & 28.6 & 41.4 & 32.9 & 43.4 \\
\hline \multicolumn{5}{|l|}{ Cigarette smoking } \\
\hline Never & 88.9 & 96.8 & 89.7 & 96.0 \\
\hline Former & 6.1 & 2.2 & 5.8 & 2.4 \\
\hline Current & 5.0 & 1.0 & 4.6 & 1.8 \\
\hline \multicolumn{5}{|l|}{ History of: } \\
\hline Induced abortion & 6.1 & 1.7 & 6.0 & 2.0 \\
\hline Miscarriage & 27.2 & 12.4 & 26.9 & 12.5 \\
\hline PID & 15.3 & 6.4 & 15.1 & 6.3 \\
\hline
\end{tabular}

Source: Reference number 6 . 
Table 2 shows among cases the prevalence of current IUD users was $9.6 \%$ (54/506), and there were fewer pregnant controls who were still using IUDs at the estimated date of conception. On the other hand, fewer cases had any past contraceptives use compared to controls. Cases and pregnant controls were similarly distributed with respect to age on past contraceptive use and current IUD analysis. However, on failure for IUD use only analysis, younger and higher educated women were more frequent among pregnant controls than cases. On past contraceptive use and current IUD use analysis, more pregnant control women than cases who had lesser gravidity were noted, less gravidity among pregnant control women than cases among failures of IUD use only analysis was noted. Prevalence of smokers among cases who smoke for 3 year or more were higher than pregnant controls.

\section{Comparison using non-pregnant controls}

Relative to women who never used IUD, women currently using IUD for 3 years or more had 2.3 times risk of tubal $\mathrm{EP}$ [adjusted OR (odds ratio) $=2.3 ; 95 \%$ confidence intervals (CI): 1.3-4.0]. In addition, women with one past IUD use episode had an increased risk to develop tubal EP, and this is more pronounced among women with two or more past IUD use episodes for 2 times or more (adjusted $\mathrm{OR}=1.5 ; 95 \% \mathrm{CI}: 1.0-2.2$, and adjusted $\mathrm{OR}=7.1 ; 95 \%$

Table 2. The percentage of cases and pregnant controls

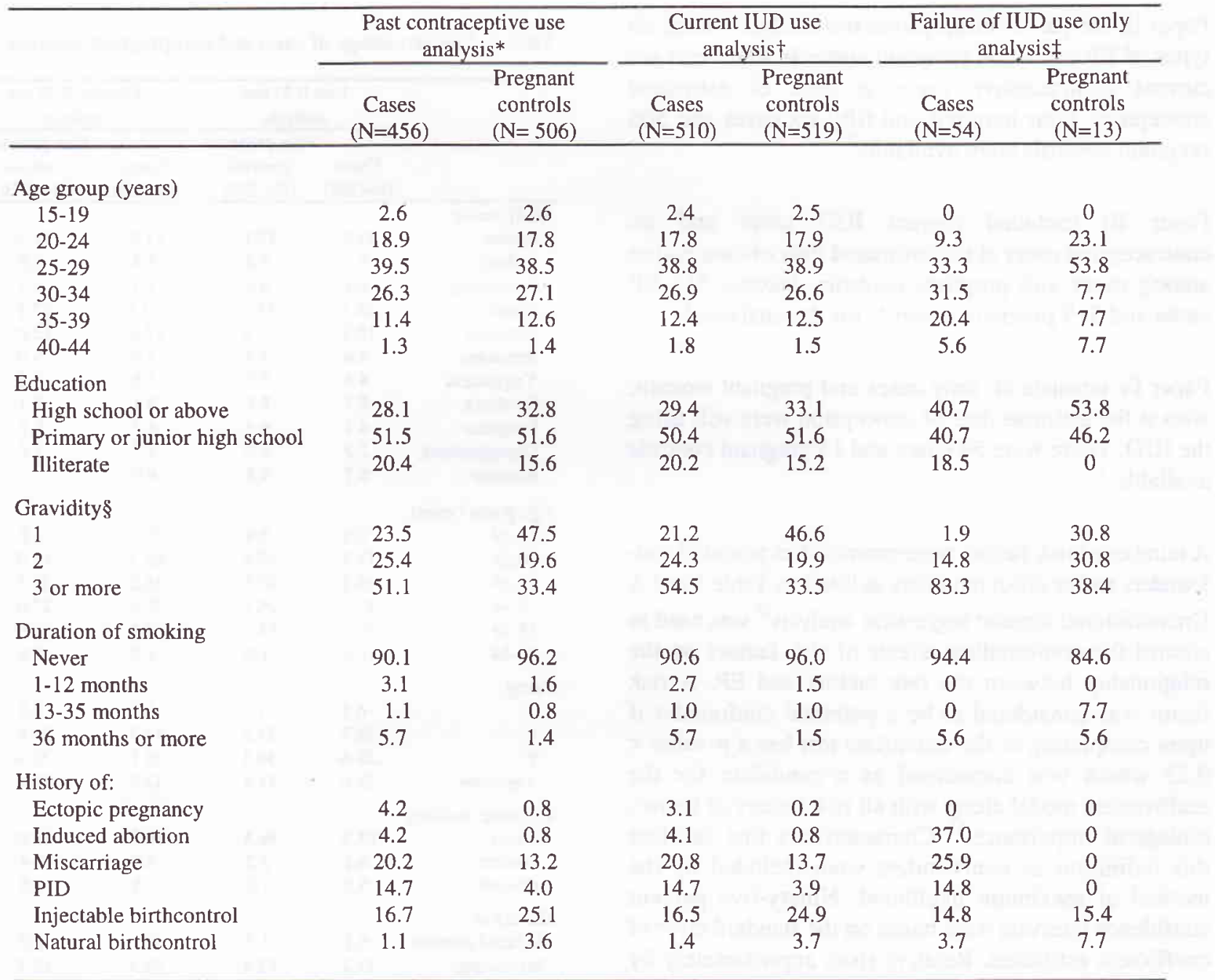

Sources: * Reference number $7 ;+$ Reference number $8 ; \ddagger$ Reference number 9 .

$\$$ For past contraceptive use analysis gravidity 1 means 0 and 1 
CI: 2.1-23.9 respectively). Furthermore, among women with only one episode IUD use, those who used an IUD for three years or more showed an increase risk to develop tubal EP (Table 3).

Table 3. Risk of tubal ectopic pregnancy associated with duration and number of episodes of past IUD use using non-pregnant controls

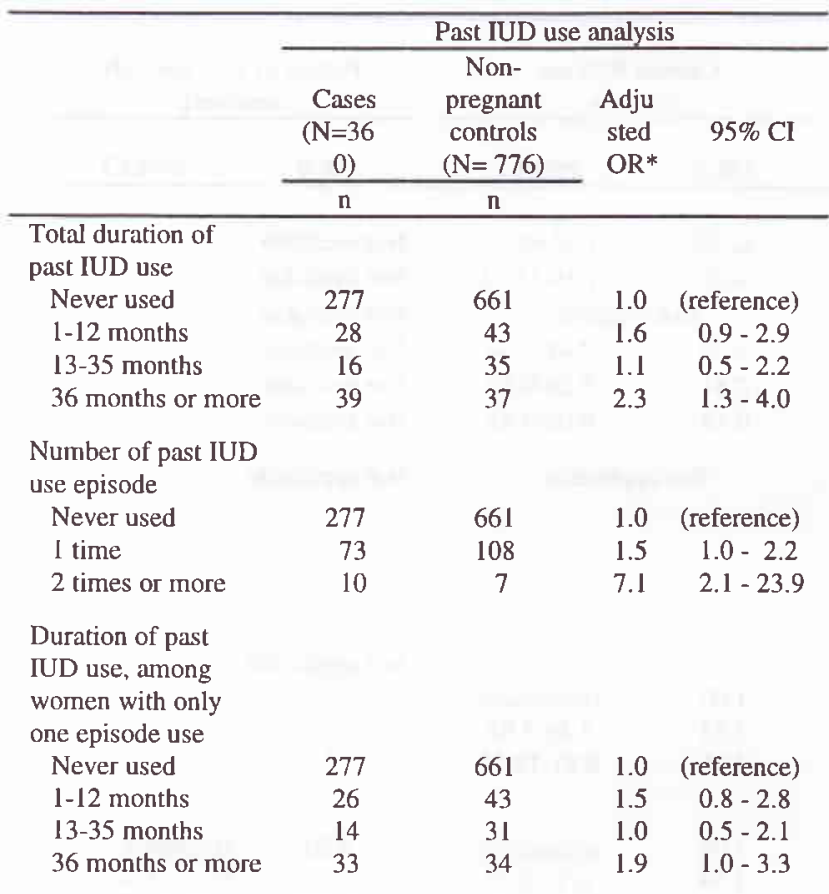

* Adjusted for age group, study center, parity, PID, and contraception at reference date. Source: Reference number 6 .

Tubal EP was less likely to develop among current IUD users relative to women who were not currently using any contraception (adjusted $\mathrm{OR}=0.2 ; 95 \% \mathrm{CI}$ : 0.1-0.3). Compared to women who were using either oral, or injectable hormonal contraceptives or to women who had been sterilized, women who were using IUD were at increased risk of tubal EP (Table 4).

Women currently using IUD for more than years had twice the risk of tubal EP than that who had used an IUD for $\leq 2$ years (adjusted $\mathrm{OR}=2.4 ; 95 \% \mathrm{CI}$ : $1.0-5.6$, based on 8 cases and 83 non-pregnant controls with $\leq 2$ years of use, and 43 cases and 164 non-pregnant controls with $>2$ years of use). In addition, for the majority of cases and non-pregnant controls using IUD at the estimated time of conception, the type of IUD reported was the Lippes loop. The type of IUD was unknown for 11 cases and 43 non-pregnant controls. ${ }^{6}$
Table 4. Risk of tubal ectopic pregnancy associated with current use of a contraceptive, analysis using non-pregnant controls

\begin{tabular}{|c|c|c|c|c|}
\hline & \multicolumn{4}{|c|}{ Current IUD use analysis } \\
\hline & \multicolumn{3}{|c|}{ Non pregnant } & \multirow{4}{*}{$95 \% \mathrm{CI}$} \\
\hline & Cases & controls & Adjusted & \\
\hline & $(\mathrm{N}=416)$ & $(\mathrm{N}=1076)$ & ORt & \\
\hline & $\mathrm{n}$ & $\mathrm{n}$ & & \\
\hline \multicolumn{5}{|l|}{$\begin{array}{l}\text { Current contraceptive } \\
\text { use }\end{array}$} \\
\hline IUD & 51 & 247 & 0.2 & $0.1-0.3$ \\
\hline None & 349 & 304 & 1.0 & (reference) \\
\hline IUD & 51 & 247 & 2.0 & $1.1-3.9$ \\
\hline Oral contraception & 16 & 161 & 1.0 & (reference) \\
\hline IUD & 51 & 247 & 3.8 & $2.0-7.5$ \\
\hline Injectable & 14 & 231 & 1.0 & (reference) \\
\hline IUD & 51 & 247 & 2.6 & $0.9-7.2$ \\
\hline Sterilization & 5 & 53 & 1.0 & (reference) \\
\hline IUD & 51 & 247 & 1.0 & $0.4-2.3$ \\
\hline Condom & 8 & 42 & 1.0 & (reference) \\
\hline IUD & 51 & 247 & - & - \\
\hline Othert & 3 & 36 & & \\
\hline
\end{tabular}

* OR among current IUD users relative to users' of other methods' of contraception. adjusted for age and study' center.

† Includes users of implants, vaginal contraceptives, withdrawal, and traditional methods.

Source: Reference number 6.

\section{Comparison using pregnant controls}

The results of the analysis using pregnant controls are shown in Table 5. Relative to women who never had history of previous EP, induced abortion, and PID, women who reported these risk factors had a consistent higher risk to be EP on the past contraceptive as well as current IUD use analysis. These risk factors were more pronounced among past IUD users. In contrast, past injectable and natural birth controls use protected women from developing EP.

Relative to non IUD users, past IUD use for 1-12 months moderately increased the risk of $\mathrm{EP}$ (adjusted $\mathrm{OR}=1.65$; 95\% CI: 0.84-3.22; $\mathrm{p}=0.145$ ). However, past IUD use for 12 months or longer protected against EP. In general, longer duration of past IUD protected against EP (test for trend $\mathrm{p}=0.015$ ). In addition, women with current IUD used for 3 years or more had 7 to 14 times increased risk of developing EP relative to women who did not use any contraceptive at estimated time of conception or a short period (1-11 months) IUD use. 
In terms of cigarette smoking habit, in general there is a trend that longer duration of smoking cigarette increase the risk of EP, although the data does not prove increased risk of EP for those who smoked for 13-35 months (Table 5).

Table 5. Risk of ectopic pregnancy associated with significant risk factors of past contraceptive use using pregnant control

\begin{tabular}{|c|c|c|c|c|c|c|}
\hline \multirow{2}{*}{ 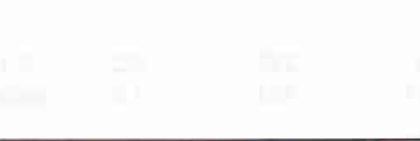 } & \multicolumn{2}{|c|}{$\begin{array}{c}\text { Past contraceptive use } \\
\text { analysis* }\end{array}$} & \multicolumn{2}{|c|}{$\begin{array}{l}\text { Current IUD use } \\
\text { analysis }\end{array}$} & \multicolumn{2}{|c|}{$\begin{array}{c}\text { Failure of IUD use only } \\
\text { analysis } \ddagger\end{array}$} \\
\hline & OR\$ & $95 \% \mathrm{Cl}$ & OR $\|$ & $95 \% \mathrm{CI}$ & OR I & $95 \% \mathrm{Cl}$ \\
\hline \multicolumn{7}{|l|}{ History of: } \\
\hline Previous ectopic pregnancy & 16.84 & $2.14-132.50$ & 12.00 & $1.52-94.51$ & Not available & \\
\hline Induced abortion & 6.70 & $2.11-21.26$ & 4.26 & $1.38-13.12$ & Not available & \\
\hline Miscarriage & 1.63 & $1.29-2.35$ & \multicolumn{2}{|c|}{ Not available } & Not available & \\
\hline PID & 4.47 & $2.57-7.76$ & 4.32 & $2.48-7.34$ & Not available & \\
\hline Injectable contraceptive & 0.51 & $0.37-0.72$ & 0.41 & $0.29-0.59$ & Not available & \\
\hline Natural contraceptive & 0.18 & $0.05-0.54$ & 0.18 & $0.06-0.52$ & Not available & \\
\hline Duration of past IUD use & & & \multicolumn{2}{|c|}{ Not applicable } & \multicolumn{2}{|l|}{ Not applicable } \\
\hline Never used & 1.00 & (reference) & & & & \\
\hline $1-12$ months & 1.05 & $0.84-3.22$ & & & & \\
\hline 13-35 months & 0.47 & $0.24-0.93$ & & & & \\
\hline 36 months or more & 0.58 & $0.36-0.94$ & & & & \\
\hline Number of past IUD use episode & \multicolumn{4}{|c|}{ Not available } & \multirow{4}{*}{\multicolumn{2}{|c|}{ Not applicable }} \\
\hline Never used & & & 1.00 & (reference) & & \\
\hline 1 time & & & 3.83 & $1.86-7.92$ & & \\
\hline 2 times or more & & & 3.96 & $0.81-19.41$ & & \\
\hline Duration of current IUD use & \multirow{6}{*}{\multicolumn{2}{|c|}{ Not applicable }} & & & & \\
\hline Never used & & & 1.00 & (reference) & 1.00 & (reference) \\
\hline 1-12 months & & & 1.59 & $0.31-8.22$ & 1.41 & $0.17-11.47$ \\
\hline 13-24 months & & & 3.09 & $0.70-13.70$ & $0.96^{* *}$ & $0.14-6.56$ \\
\hline 25-35 months & & & 1.46 & $0.46-4.61$ & & \\
\hline 36 months or more & & & 14.11 & $3.26-61.00$ & 7.51 & $0.90-62.9$ \\
\hline $\begin{array}{l}\text { Duration of current IUD use, among } \\
\text { women with only one episode use }\end{array}$ & \multirow{5}{*}{\multicolumn{2}{|c|}{ Not applicable }} & & & \multirow{5}{*}{\multicolumn{2}{|c|}{ Not available }} \\
\hline Never used & & & 1.00 & (reference) & & \\
\hline 1-12 months & & & 1.37 & $0.24-7.72$ & & \\
\hline $13-35$ months & & & 2.30 & $0.47-11.33$ & & \\
\hline 36 months or more & & & $\begin{array}{l}2.19 \\
1.79\end{array}$ & $\begin{array}{l}0.57-8.44 \\
2.68-5] 85\end{array}$ & & \\
\hline Duration of smoking & & & & & \multirow{5}{*}{\multicolumn{2}{|c|}{ Not available }} \\
\hline Never smoked & 1.00 & (reference) & 1.00 & (reference) & & \\
\hline $1-12$ months & 2.76 & $1.09-6.97$ & 3.04 & $1.21-7.67$ & & \\
\hline 13-35 months & 0.81 & $0.17-3.91$ & 0.73 & $0.18-2.89$ & & \\
\hline 36 months or more & 3.20 & $1.30-7.83$ & 2.66 & $1.14-6.19$ & & \\
\hline
\end{tabular}

Sources: * Reference number $7 ;+$ Reference number $8 ; \ddagger$ Reference number 9

$\$$ Adjusted each other between applicable listed risk factors in this column

"I Adjusted each other between applicuble listed risk factors in this colunn, education, and gravidity

I Adjusted for number gravidity and smoking habit (ves/no)

** For 24-35 months IUD use 


\section{DISCUSSION}

There are several limitations, which must be considered in the interpretation of the findings. Firstly, case ascertainment, although based on a defined population, may be incomplete, as some women may have received medical care for their EP at a private hospital which was not participating in our study. However, although there are private hospitals operating within the study areas, the large majority of EP cases are treated at the teaching hospitals from which our cases were identified. In addition, there is no data regarding the proportion of the replacement of the controls.

Secondly, different individuals interviewed cases and controls. However, all interviewers have been similarly trained in the use of the data collection instrument.

Thirdly, we have no data on the aspect of an IUD and other contraceptive methods use that might have allowed us to more specifically examine risk factors associated with the last timing of these contraceptive methods used.

Fourthly, in the analysis using non-pregnant controls, the cases were limited only to tubal EP, whereas in the analysis using pregnant controls all types of EP (intramural cornual, ovarian, tubular abortion, other type of EP, as well as tubal EP) were included. In addition, the past IUD use analysis using non-pregnant control was specially designed to examine the effect of IUD use on tubal EP, in which a number of subjects of nulligarvid, prior EP, sterilized husbands were excluded for this analysis.

In spite of these limitations, the restriction of our study population to married women made our results more directly applicable than those of prior studies. Although we do have some evidence that pregnant and nonpregnant controls were representative of the general population, as $22.1 \%$ of the total non-pregnant controls interviewed reported current use of an IUD, in which similar to overall proportion of IUD use (22.2\%) anong Indonesian women in the area which was this study was conducted (personal communication, Indonesian National Family Coordinating Board). In addition, pregnant and non-pregnant controls were selected randomly from a random subset of neighborhoods within the same catchment area as that of cases.

In the interpretation of the results of the analysis, the fundamental problem is control definition.
The analysis using pregnant controls compared the odds of ectopic nidation in case and controls. Analysis using pregnant controls describe the risk of EP only for those who are currently pregnant, therefore, describe the probability of nidation. On the hand, the analysis using non-pregnant controls compared the odds of pregnancy and subsequent ectopic nidation, i.e., the cumulative effect of two probabilities of achieving conception and a subsequent ectopic nidation. ${ }^{5,13}$

The identified risk factors in the analysis using pregnant controls interfere with both probabilities. For example, prior EP, cases which needed tubal surgery leads to decrease the probability of conception but increases risk of the probability of ectopic nidation once a pregnancy occurs.

Although implants at various sites may have different etiologies, but most studies have not considered site specificity of effect, ${ }^{2}$ thereby in this paper, the analysis using pregnant controls included all types of EP.

The results of analysis using non-pregnant and pregnant controls seem to be inconsistent on some risk factors for EP. To examine this inconsistency, a meta-analysis approach is used to provide a chance to explore the reason behind inconsistent findings. ${ }^{14}$

\section{Contraceptive use}

Comparison with non-pregnant controls, the results suggest that current IUD use may provide a substantial degree of protection against tubal EP relative to those not using contraception. In settings in which the IUD is the sole method of contraception available, its use (prior to discontinuation) would thus be expected to reduce the risk of tubal EP. In other possibility setting where multiple contraceptive options are available, many women who had chosen to use IUD could otherwise select some other method of contraception, rather than choosing not to use contraception. Among such women for whom hormonal contraceptive use and/or tubal sterilization is an acceptable and available option, the results indicate that risk of tubal EP pregnancy may be increased while using IUD. ${ }^{(6)}$

Result of analysis using non-pregnant controls (Table 3) shows that women who had discontinued using IUD had an increased risk of tubal EP relative to those who had never used IUD. This increase was most pronounced in women who reported multiple episodes of IUD use and, 
to a lesser extent, in women with a long (3 year or more) duration of IUD use. These associations observed are similar to those previous reported studies conducted in developed countries. ${ }^{(4,15)}$

The risk of EP associated with past IUD use for a duration of three years or more and number of IUD use episode of two times or more using non-pregnant controls is higher than the result of the analysis using pregnant controls. Most likely, in the analysis using nonpregnant controls, the cases were limited only to tubal $\mathrm{EP}$, whereas in the analysis using pregnant controls included all types of EP (intramular/cornual, ovarian, tubular abortion, other types, as well as tubal EP). In addition, the analysis using non-pregnant control was specially designed to examine the effect of IUD use on tubal EP, where a number of subjects were excluded as mentioned in the limitation of this paper. However, in the analysis using pregnant controls, the excluded subjects as indicated in the analysis using non-pregnant controls were not excluded.

The results of past contraceptive analysis using pregnant controls as shown on Table 5 indicate that past IUD use, in general, protected women from develop EP. However, past IUD use for a shorter period (1-11 months) had a moderate increase risk for EP, and those who used IUD for a longer period had a lower risk. Others ${ }^{16,17}$ have noted that risk of symptomatic, diagnosed PID in IUD users is greatest shortly after insertion. Most likely, those who used IUD for a short period of time were those who could not afford longer IUD use, and only "healthy" women a longer period of IUD use. This situation is analog to "healthy worker effect."

In contrast, analysis using pregnant controls, among current IUD users compared to those who were not on contraception as well as compared to those using IUD for 1-11 months reveals that IUD use for 3 years or more showed a significant increase in the risk of EP. The results were similar with the prior studies. ${ }^{1-4}$ This means, that once the IUD fails and pregnancy occurs, the risk of EP increases. Apparently IUD protects against intrauterine pregnancy rather than EP.

Comparison using pregnant controls, past use contraceptive analysis results showed that past IUD use, injectable, and natural contraception uses protected against EP. The protecting effect of past IUD use against EP is agreement with the previous meta-analysis report. ${ }^{(3)}$

Past and current injectable contraceptive use was found to be lowering the risk for EP. This is understandable, since injectable (progesterone only) contraceptive suppresses ovulation, altering motility of the fallopian tube, and interrupting endometrial development. Natural method (coitus interruptus) prevented EP by means of less probability of having an infection along with ejaculated semen.

\section{Gynecological history}

The main finding of the comparison using pregnant controls related to gynecological history factors i.e. history of previous EP, induced abortion, miscarriage, $\mathrm{PID}$, smoking habit. The results indicate that previous EP was strongly associated with EP based on the result of past contraceptive use analysis, and to a lesser extent on current IUD analysis. The lesser extent of previous EP risk on the current IUD analysis showed that the strong association of previous EP on the result of past contraceptive use analysis was "diluted" by current IUD use on current IUD use analysis. In the current IUD analysis, the model included current IUD risk factor (also a strong risk factor), whereas in the past IUD use analysis, current IUD use was not included.

The comparison using pregnant controls, the results of analysis of past any contraceptive use analysis indicate that the risk of EP associated with prior EP, induced abortion, and PID is stronger than the results of current IUD use analysis. This condition were most likely due to the final model on the current IUD analysis, including current IUD use, whereas in the final model of analysis of past IUD use, current IUD uses were not included. Current IUD use was one of the strong risk factors. Therefore, the effect of prior EP, induced abortion, and PID were "diluted"by current IUD use. In general, the results of this study in Indonesia are in agreement with the previous reports ${ }^{1,2,5}$ which indicated that EP is highly associated with prior EP, induced abortion, and PID.

\section{Smoking habit}

The risk of EP in relation to smoking habit were shown in the past contraceptive use and current IUD use analysis. There was a decreased risk of EP among women who smoked for 13-35 months, but the trend on both analyses is that longer duration of smoking increased risk of EP (test for trend for both analyses $\mathrm{p}<$ 0.001 ). This is in agreement with previous reports $1,2,5$ that smoking is thought to affect tubal motility, thus increasing the risk of ectopic nidation. 
It is recommended for non-pregnant women, in settings in which the IUD use is the sole method of contraception available, IUD use would reduce the risk of tubal EP, with a special attention to those having used IUD for 3 years or more with an increased risk of tubal EP. If multiple contraceptive options were available to these women, who had chosen to use IUD, they would otherwise select some other method of contraception (hormonal contraceptive, tubal sterili-zation) which were lower in the risk of tubal EP.

Since at present, current noninvasive diagnostic methods that allow early diagnosis of EP (even before appearance of any symptoms) are available, it is recommended that to those women with increased risk associated with the identified risk for EP, in particular previous EP, induced abortion, miscarriage, pelvic inflammatory disease, smoking habits, and current IUD use for 3 years or more, early diagnosis and prompt treatment, also family planning counseling program be provided.

\section{Acknowledgment}

The author thanks Dr. Olav Meirik (Special Program of Research, Development and Research Training in Human Reproduction, World Health Organization) and Dr. Sujana Jatiputera (School of Public Health University of Indonesia) for technical assistance in the preparation on the study.

Special thanks are extended to Dr. ESP Pandi who encouraged me to be the principal investigator in this study. Special thanks to Dr. Mary Anne Rossing (Fred Hutchinson Cancer Research Center, Seattle USA) for data verification and transformation of the study. Special thanks to colleagues in 11 centers in Indonesia for their high dedication in participating the study. And lastly, to Dr. Abdul Bari Saifuddin and Dr. Isnani S. Suryono to review earlier drafts of this manuscript that improved the final product.

\section{REFERENCES}

1. World Health Organization. Task Force on Intrauterine Devices for Fertility Regulation. A multi-national case-control study of ectopic pregnancy. Clin Reprod Fertil 1986;3:131-4.

2. Chow WH, Daling JR, Cates W, Greenberg RS. Epidemiology of ectopic pregnancy. Epidemiol Review 1987;9:70-88.

3. Xiong X, Buekens P, Wollast E. IUD use and the risk of ectopic pregnancy: A meta-analysis of case-control studies. Contraception 1995;52:23-34.

4. Mol BJW, Ankum WM, Bossuyt PM, Veen vD. Contraception and the risk of ectopic pregnancy. Contraception 1995;52:337-41.

5. Ankum WM, Mol, Veen Fvd, Bosyut PM. Risk factors for ectopic pregnancy: A meta-analysis. Fertil Steril 1996;65:10939.

6. Basuki B, Rossing MA, Daling JR. Intrauterine device use an risk of ectopic pregnancy: An Indonesia case-control study Intl J Epidemiol 1994;23:1000-5.

7. Basuki B. Risk of ectopic pregnancy associated with gynecological history, past contraceptive use, and smoking habit. Med J Indones 1999;8:182-9.

8. Basuki B. The number of episodes and duration of current IUD use and risk of ectopic pregnancy. Med J Indones 1999;4:252-9.

9. Basuki B. Duration of current IUD use and risk of ectopic pregnancy. Indones J Obstet Gynecol 1999;23:82-7.

10. Breslow NE, Day NE. Statistical methods in cancer research. Vol I. The analysis of case-control studies. IARC Scientific Pub. No.32. Lyon: Intemational Agency for Research on Cancer; 1980.

11. Hosmer DW, Lemeshow S. Applied logistic regression. New York: John Willey \& Sons; 1989.

12. Statistics and Epidemiology Research Corporation. Egret: Reference manual. Seattle: The Company; 1990.

13. Weiss NS, Daling JR, Chow WH. Control definition in casecontrol studies of ectopic pregnancy. AJPH 1985;75:67-8.

14. Greenland S. A critical look at some popular meta-analytic methods. Am J Epidemiol 1994; 140:290-6.

15. Rossing MA, Daling JR, Voigt LF, et al. Past use of intrauterine device and risk of tubal ectopic pregnancy. Epidemiology 1993;4:245-252.

16. Farley TMM, Rosenberg MJ, Chen J-H, Meirik O. Intrauterine devices and pelvic inflammatory disease: an international perspective. Lancet 1992;339:785-8.

17. Lee NC, Rubin GL, Ory HW, Burkman RT. Type of intrauterine device and the risk of pelvic inflammatory disease. Obstet Gynecol 1983;62:1-6.

18. Arrighi HM, Hertz-Piciotto I. The evolving concepts of the healthy worker survivor effect. Epidemiology 1994;5:186-96. 